Ruth Dassonneville

\title{
Ellen Quintelier
}

Marc Hooghe

Ellen Claes

\section{The impact of civic education on political attitudes and behavior A two-year panel study among Belgian late adolescents}

\author{
Applied Developmental Science, accepted
}

\begin{abstract}
It is generally assumed that civic education efforts will have a positive effect on the political attitudes and behaviors of adolescents and young adults. There is less agreement, however, on the most effective forms of civic education. In the present study, we distinguish between formal civic education, an open classroom climate and active learning strategies, and we explore their effect on political interest, efficacy, trust and participation. To analyze these effects, we rely on the results of a two-year panel study among late adolescents in Belgium. The results indicate that formal civic education (classroom instruction) and active learning strategies (school council membership and, to a lesser extent, group projects) are effective in shaping political attitudes and behavior. An open classroom climate, on the other hand, has an effect on political trust. We conclude that there is no reason to privilege specific forms of civic education, as each form contributes to different relevant political attitudes and behaviors.
\end{abstract}

\section{KEYWORDS}

civic education, panel study, Belgium, political attitudes, political participation 


\section{Introduction}

Traditionally, civic education efforts have raised high expectations. It is assumed that civic education will help prepare adolescents for their future role as citizens in a democratic society (Galston, 2004; Torney-Purta, 2002; Youniss, 2011). As a result of growing social and academic concerns about the vitality of civic culture in Western democracies, various countries and education systems have stepped up their civic education efforts in recent years (Pasek, Feldman, Romer, \& Jamieson, 2008). Current research, however, provides little information about the effects of these efforts, and skeptics would argue that increased civic education efforts have apparently not turned the tide of declining political participation levels among young age groups (Malin, 2011). It therefore remains to be investigated whether these efforts actually contribute to the development of democratic attitudes and behaviors and, more specifically, which educational practices can be expected to have an effect on specific outcomes.

The available research on the effects of civic education suffers from a number of problems and shortcomings. It has to be noted that civic education itself has changed dramatically over the past decades. While past efforts focused on cognitive effects and on cultivating patriotism among pupils, the scope of civic education has been vastly expanded in recent decades (Sapiro, 2004). It has been emphasized that schools themselves should function as a democratic community (Campbell, 2008), while service learning has been introduced or reinforced in order to promote active citizenship (Hart, Donnelly, Youniss, \& Atkins, 2007). The existing research literature, however, does not allow us to identify the most effective practice for engendering civic identity among adolescents and young adults. The explicit goal of the current study is to compare the effects of these different forms of civic education. 
From a methodological perspective, too, a number of shortcomings in the current research literature can be identified. First, as suggested by the discussion above, it is essential that measurements are multidimensional, comprehensive and valid, which means that they should cover the whole range of civic education initiatives now being offered both within and outside the curriculum. Such measurements allow us to determine what format contributes most strongly to the development of attitudes and behavioral patterns. Second, studies should ideally be longitudinal, with outcomes measured at a later time than the intervention. Although various studies are available, most are purely cross-sectional, thus limiting the validity of the conclusions that can be drawn about the effectiveness of civic education. Third, and almost self-evidently, as pupils are nested in class and school contexts, multilevel analysis techniques are required, and these techniques were not widely available in the older literature.

The goal of the current article is to explore the effects of distinct civic education practices on political attitudes and behaviors, while addressing the shortcomings mentioned above. First, we use a wide and comprehensive measure of both civic education efforts and assumed outcomes of civic education. Different indicators are used to measure civic education, i.e. formal civic education, an open classroom climate and active learning strategies. Furthermore, we assess the impact of these three forms of civic education on political interest, efficacy, trust and participation. Second, while most existing research is based on US schools, this article focuses on a non-US sample to explore the effects of civic education. Third, whereas most previous studies have been correlational in design, we rely on a representative two-year panel study among Belgian late adolescents, which should allow us to track the effects of civic education over a relatively long observation period. . Fourth, multilevel regression techniques are used, allowing us to take class and school level effects 
into account. The article is structured as follows: first, we briefly review the literature on current developments in civic education research as well as the available research on the effect of the three civic education strategies, before presenting data and methods. After presenting the results of the analysis, we conclude with some observations on the effectiveness of different civic education methods.

\section{Literature}

The debate about the contribution of various forms of civic education to the development of democratic attitudes is certainly not a new one (Easton \& Dennis, 1967; Hess \& Torney, 1967). Classical studies from the 1960s already used Dewey's notion of a 'democratic school', emphasizing that civic education classes were not the only method of fostering active citizenship, but that one should also pay attention to the democratic participation opportunities offered by the school environment itself. Youniss, McLellan and Yates (1997) offered evidence showing that participation in compulsory community service was associated with higher levels of volunteering after graduating from high school. Extracurricular activities were also shown to have a strong effect (Smith, 1999). What these studies demonstrate is that the widening range of civic education activities since the 1970s indeed seems to have an effect on political attitudes and behaviors.

In line with the literature, we will distinguish three kinds of civic education in this analysis: formal civic education, an open classroom climate and active learning strategies.

The first type, i.e. formal civic education, is primarily aimed at the acquisition of political knowledge. As political knowledge directly influences other political attitudes, it is assumed that if students gain an understanding of how parliament works, they will also be more strongly interested in politics and the functioning of political institutions (Delli Carpini 
\& Keeter, 1996; Verba, Schlozman, \& Brady, 1995). We can therefore assume that formal classroom instruction will mainly have a cognitive effect on pupils.

The second type of civic education can be described as an open classroom climate. The more recent literature highlights the role of democratic practice and of classroom interaction between students or between teacher and students (Torney-Purta, Lehmann, Oswald, \& Schulz, 2001). This line of literature argues that a democratic civic culture is not primarily a matter of factual knowledge about the functioning of the political system, but depends on the degree to which the basic democratic attitudes and normative expectations are shared by the population. The way in which the school itself functions as a small-scale democratic community is receiving increasing attention in the literature (Flanagan \& Stout, 2010). From this perspective, it could be argued that it is more important that the school itself should be run democratically than that students are taught about the workings of democracy. This approach is commonly operationalized by the concept of an 'open classroom climate', a notion which refers to the way in which students are encouraged to develop and express their own views (Campbell, 2006; Torney-Purta, et al., 2001). It can be assumed that the presence of an open classroom climate will have an effect on students' efficacy and trust levels.

The third form of civic education is the use of active learning strategies. Various strategies can be distinguished, but what they all have in common is that they encourage students. These methods encourage students to participate actively in society and in democratic procedures, either within or outside school, thereby acquiring political skills, attitudes and realistic expectations about the political process (Galston, 2004; Torney-Purta, 2002). In this article, we will focus on four active learning strategies, i.e. participating in group projects, visiting parliament or the town hall, being a member of a school council and participating in service learning, all of which can teach students about collaborating with others, the problems of society etc. Thus, democratic processes of consultation and decision- 
making can play an important role in strengthening young people's political interest (TorneyPurta \& Vermeer, 2006). By participating in a school council or in group projects, they can learn politically relevant skills (e.g. discussion, consultation, compromise), which may positively affect their political attitudes. Young people develop a sense of social justice by collaborating with others and by taking up their role and responsibilities as citizens (Campbell, 2006; Conway, Amel, \& Gerwien, 2009; Quintelier, 2010). A final active learning strategy consists of visiting parliament or inviting government officials or politicians to the classroom. Such encounters render politics less abstract and allow adolescents to see politicians as 'real' people. It is assumed that these kinds of activities will make adolescents more willing to take part in political life. Active learning strategies can therefore be expected to mainly affect participation or the intention to participate in civic life.

\section{The effect of civic education on political attitudes and behavior}

As was already mentioned, it is also important to consider various possible outcomes of civic education. More specifically, we will focus on political interest, political efficacy, political trust and political participation. The literature suggests that late adolescence is a critical period for the development of these outcomes (Lerner, Phelps, Forman, \& Bowers, 2009).

First, we focus on political interest. When adolescents learn about politics, this can be expected to have a positive effect on their level of political interest (Delli Carpini \& Keeter, 1996; Glanville, 1999; Verba, et al., 1995). The available research provides evidence for a reciprocal relationship: on the one hand, Schmid (2003) shows that students already interested in politics are more likely to take subjects such as civic education; on the other hand, students 
taking such classes also tend to develop higher levels of political interest (Zukin, Keeter, Andolina, Jenkins, \& Delli Carpini, 2006).

A second attitude is political efficacy, i.e., the feeling that one can have a meaningful impact on political decision-making. In order to develop a sense of political efficacy, citizens need to feel that (even as a young person) they can have an influence on politics. ${ }^{1}$ Schools can support their students by engaging them in activities through which they help others in society or develop their political skills. Pasek et al. (2008) demonstrated that young people who participated in a Student Voices program developed a stronger sense of political efficacy. In this US civic education program, participants reported problems in their community and investigated what politicians were doing to address these problems. Up to two years after completion of the program, participants were found to have greater political efficacy than their peers who did not take part in such a project. Kahne and Westheimer (2006) show that projects do not need to be large-scale: even more modest projects provide adolescents with the opportunity to increase their sense of political efficacy. An essential condition is that they should feel able to make a significant contribution: they may not be able to eradicate poverty, but they can help at a local soup kitchen, for instance. Moreover, in order to influence political efficacy, adolescents should also be encouraged to discuss and reflect on the volunteer work in class (Conway, et al., 2009).

A third political attitude is political trust, more specifically the trust in political institutions such as parliament and government. If experience with a democratically run school leads to a higher level of trust in this specific institution, we can expect this feeling of trust to be extended to political institutions in general. This expectation is confirmed by empirical research showing a positive relationship between an open classroom climate and the level of political trust (Claes, Hooghe, \& Marien, forthcoming). In an earlier study, Fridkin et 
al. (2006) found that opportunities for practicing democratic skills in class were associated with higher levels of political trust among students.

A fourth dependent variable is political behavior, more specifically political participation, which is considered to be one of the most important aspects of active citizenship (Dalton, 2007). There are various ways in which schools can encourage their students to participate in politics. As political participation requires political skills, we can expect active learning strategies to have a positive effect on political participation. Research has shown that engagement in social activities in associations is associated with higher levels of political participation (Beck \& Jennings, 1982; McFarland \& Thomas, 2006; Quintelier, 2008). Other authors have also demonstrated a positive effect of school activities on civic participation. Research has indicated that service learning, classroom civic learning and after-school activities can have a positive effect on civic participation (Kahne \& Sporte, 2008).

This literature reviewed above yields the following three hypotheses:

H1. The experience of civic education will be associated with higher levels of political interest.

H2. The experience of an open classroom climate will be associated with higher levels of political efficacy and political trust.

H3. The experience of active learning strategies will be associated with higher levels of political participation.

To date, most of these relations have only been studied cross-sectionally in the international literature (thus providing only correlational information). In contrast, the current study is longitudinal and examines the effects of civic education experiences over a two-year observation period. 


\section{Data}

The data for this study were derived from the Belgian Political Panel Survey (BPPS), a two-wave panel study among 16- and 18-year-olds. This is the age group at which most civic education efforts are targeted (Hooghe \& Claes, 2009). Moreover, from a developmental perspective, students' attitudes can also be expected to be more easily influenced at this age (Hooghe \& Wilkenfeld, 2008).

In 2006, a representative survey was conducted among 6,330 sixteen-year-olds in Belgium. An analysis of the survey responses confirmed that the sample was representative for region, school type, gender and educational track. The sample was drawn using a two-step procedure. First, schools were randomly selected from the official records obtained from the Belgian educational authorities. The sample was stratified by region, language, and private versus public education. Subsequently, these randomly selected schools were visited by the researchers, and about 50 pupils from the $4^{\text {th }}$ grade $\left(10^{\text {th }}\right.$ grade in the US system) were invited to participate. These respondents were chosen randomly and depending on their availability in a given time slot. Since this study was conducted during class hours, participation was nearly universal. As schooling is compulsory until the age of 18 in Belgium, we can be confident that almost all 16-year-olds are indeed enrolled in a school.

In 2008, the respondents were surveyed for a second wave, this time at the age of 18 . While most of the initial respondents were still at the same school, alternative strategies had to be developed to reach those who had dropped out or had changed schools. Of the initial 112 schools, 109 participated again in the 2008 survey. In these schools, the same classes were re-surveyed, which involved re-interviewing 2,988 students. The other students were 
contacted through a mail survey. In total, 4,235 students (or 67 percent) from the initial panel were re-surveyed. The attrition rate was in line with what could be expected for this type of panel study (Groves \& Peytcheva, 2008; Jennings, Stoker, \& Bowers, 2009; Olson \& Witt, 2011; Snow, Tebes, \& Arthur, 1992). While the level of attrition is worrisome and needs to be controlled for, it did not invalidate the findings of the panel survey (Lynn, 2009). A separate attrition analysis demonstrated that there was no significant difference between respondents who dropped out of the panel and those who participated twice with regard to initial levels of political interest and political participation. With regard to these two dependent variables, we can therefore be quite confident about the validity of our findings. We did observe a significant difference, however, with regard to the initial levels of political trust and internal political efficacy. Given this selective attrition pattern, this implies that our findings might be less robust for these two variables. The second wave was again representative with regard to region, school type, gender and educational track. ${ }^{2}$ Hence, this dataset is ideally suited to test our hypotheses. It provides access to a total sample of 4,235 panel respondents interviewed both in 2006 (average age 16) and in 2008 (average age 18) (Hooghe, Quintelier, Claes, \& Dejaeghere, 2009).

It should be pointed out that Belgium is a bilingual, federal country, in which the authority for school curricula rests with the Dutch and French language communities. In recent years, both communities have launched a range of cross-curricular civic education initiatives (Hooghe \& Claes, 2009). This cross-curricular approach implies that civic education is not a separate subject but is integrated in various courses across the curriculum. Educational authorities expect that such cross-curricular civic education activities will help ensure that schools can serve as a training ground for democracy. ${ }^{3}$ In order to control for differences between the two language communities, language was always included as a 
control variable in the analysis. As the Belgian education system is fully segregated, schools can be strictly divided between Dutch and French language schools (there are no bilingual schools).

\section{Measures}

As stated in the introduction, we differentiate between three main types of civic education. With regard to formal civic education, respondents were asked about specific topics that were discussed in class. The six topics included in the analysis were the functioning of parliament, the United Nations, the European Union, federalism, elections and recent political events. As these items were strongly related (Cronbach's $\alpha$ : 0.84; Eigenvalue: 3.35; explained variance: 55.89), they could be included in a zero-to-ten 'classroom instruction' sum scale.

A second type of civic education is labeled 'open classroom climate', as it is assumed that this type of education allows students to learn about democracy by being in a school that constitutes a small-scale democracy. The notion of an open classroom climate was operationalized in two different ways. First, we used a traditional (Torney-Purta, 2002) threeitem scale, whose most characteristic item was "Students are encouraged to make up their own minds about issues". These items were related (Cronbach's $\alpha$ : 0.60; Eigenvalue: 1.67; explained variance: 55.70) and could thus be combined into a sum scale (see appendix for full wording) ${ }^{4}$ In addition, we asked respondents whether they had a say on issues such as school discipline or the teaching agenda (joint decision making). These six items $(0=$ no say, $1=\mathrm{a}$ say) proved to form an internal coherent scale (Cronbach's $\alpha$ : 0.68; Eigenvalue: 2.38; 
explained variance: 39.71). The sum scale of these items was used to assess the degree of democratic decision-making at school.

Finally, we included a number of variables that measured the presence of active learning strategies. First, we included an indicator of whether and to what extent pupils had cooperated in group projects in class. Further, we included an indicator of whether and how often pupils had to do voluntary work as a school assignment. Thirdly, we also added a sumscale variable for 'visiting parliament or the city hall' and 'guest lecture by a politician or important public figure to the analysis. A final variable included in the analysis was whether or not the respondent was actively involved in the school council.

A shortcoming of the present survey, however, is that we had to rely on perceptions of civic education efforts. Hence, stronger effects might be found because participants with higher levels of political attitudes, for instance political interest, are more likely to remember an activity that they perceived as civic education. Partly, we can account for this by controlling for the political attitudes in 2006 , as we will do in the final analyses. Nevertheless, it has to be acknowledged that these civic education measurements are predominantly quantitative, and they do not probe into the perceived quality of these experiences. As there is no standard method to assess the quality of civic education efforts, , it was impossible to include a quality assessment. ${ }^{5}$

In this article, we analyze the effect of civic education on four dependent variables. In order to isolate the effect of civic education, we also included the first measurement of the dependent variable in 2006 as a control variable to explain the same variable two years later. The independent variables were measured in the first wave of the survey (2006), while the dependent variables were measured in the 2008 wave. This two-year time-lag between 
independent and dependent variables strengthens - although it does not prove - causal claims about the effect of school experiences on the political attitudes investigated. In both waves of the panel study, the dependent variables were measured in exactly the same manner, except for political efficacy, which was measured using one indicator during the first wave.

As is customary in political science research, political interest was measured using a single item measurement, i.e. by asking respondents how interested they were in political affairs and social problems. Response categories ranged from 1 (not at all interested) to 4 (extremely interested).

The second dependent variable included in the analysis was internal political efficacy. This attitude was measured by means of a four-item scale, with items such as "Sometimes politics is so complicated that someone like me cannot understand what is going on" (reverse coding, i.e., a higher score represented a a greater feeling of understanding). The scale proved to be internally coherent (Cronbach's $\alpha$ : 0.69, Eigenvalue: 2.10 , explained variance: $52.73 \%$ ). It should be noted, however, that during the first wave of the study, political efficacy was not measured by means of a scale, but only by a single item. Nevertheless, this allows for valid comparison with the pre-existing attitude, given that the Pearson correlation coefficient between this single item and the remainder of the scale was .51 in the second wave. ${ }^{6}$

Third, we investigated political trust. This variable was operationalized as a sum scale of respondents' scores on five items. We included respondents' level of trust (on a zero-to-ten scale) in the Belgian parliament, the regional parliament, the European parliament, the federal government and political parties (in 2006: Cronbach's $\alpha$ : 0.93; Eigenvalue: 3.91; explained variance: $78.16 \%$; 2008: Cronbach's $\alpha$ : 0.92, Eigenvalue: 3.76 , explained variance: $75.27 \%$ ). 
The final dependent variable included in the analysis was political participation. We used a battery of ten different activities (ranging from 'signing a petition' to 'contacting a politician'), and respondents were asked to indicate whether or not they had participated in this type of activity. These ten items (see appendix) also formed a reliable index, ranging from 0 (respondent did not participate in any of these activities) to 10 (respondent participated in all activities) (2006: Cronbach's $\alpha$ : 0.60; Eigenvalue: 2.26; explained variance: 22.61; 2008: Cronbach's $\alpha$ : 0.65; Eigenvalue: 2.51; explained variance: $25.11 \%$ ).

\section{Methods}

As students are nested in classes and in schools, the independence of observations assumption is violated, which indicates that multilevel analysis is necessary. Three levels were distinguished in the data: the individual level $(n=4,226)$, the class level $(n=422)$ and the school level $(\mathrm{n}=109)$. As the dependent variables were situated at the individual level and the explanatory variables at each of the three levels discerned, hierarchical linear modeling was used (Hox, 2010). In addition to the dependent variables, the variables measured at the individual level included language, gender, socio-economic status and active involvement in the school council. Socio-economic status was measured by a factor score of educational track (vocational, technical or general education), educational goal (measured by a question about the student's highest educational goal, ranging from high school dropout to university) and the number of books at home (ranging from $1=$ zero to $7=$ more than 500 ). We opted for this factor solution because it allowed us to incorporate the multidimensional character of socioeconomic status and because these items are highly correlated. Self-evidently, the control variables for political attitudes in 2006 were also measured at the individual level. At the class level, we included the variables 'experience with group projects', 'voluntary work', 'political 
visits' and 'talking about politics in class'. Although these elements were measured at the individual level, we aggregated them to the class level: students are likely to remember and report their civic education experiences differently depending on their level of interest in politics, and this type of measurement error was therefore avoided by aggregating responses to the class level. ${ }^{7}$ Further, we aggregated the elements 'joint decision making' and 'open classroom climate' (which were also measured at the individual level) to the school level, as the school governance literature suggests that school characteristics and school leadership determine the climate that pupils experience at school (Griffith, 1999). Moreover, the questions used to measure these variables were mostly phrased as referring to schools and not to classes. ${ }^{8}$

The following models were used in the analysis:

Political Interest $t_{\text {time } 2}=\gamma_{000}+\gamma_{001} *$ Joint Decision Making $+\gamma_{002} *$ OpenClassroom climate $+\gamma_{010} *$ Classroom Instruction $+\gamma_{020} *$ Group Projects $+\gamma_{030} *$ Volunteering + $\gamma_{040} *$ Visiting public building $+\gamma_{100} *$ Language $+\gamma_{200} *$ Gender $+\gamma_{300} *$ SES $+\gamma_{400} *$ School Council $+\gamma_{500} *$ Political Interest time $1+r_{0}+u 00+e$

For the other three dependent variables, the formal expression is more or less the same (not repeated for space reasons).

\section{Results}

We first investigated the effect of civic education at school on political interest (Table 1). It was expected that particularly classroom instruction would increase students' level of interest in politics (Hypothesis 1). The regression results in Table 1 show that the control 
characteristics included in the analysis indeed have a strong effect on political interest. Boys are significantly more interested in politics than girls, and a higher socioeconomic status also leads to higher levels of political interest.

In Model I, the hypothesis is confirmed, and we can observe a strong and significant association between classroom instruction and political interest. There is only a limited effect of an open classroom climate, but a strong relation with having done group projects. In the Model II, we controlled for students' level of interest in politics: the results show that the level of interest measured in 2006 is a very strong predictor of political interest in 2008. Political interest can thus be considered as an attitude that remains quite stable over time. While the effect of classroom instruction is strongly reduced in this model, it does remain significant, thus confirming our first hypothesis. In this model, the effect of an open classroom climate is rendered non-significant, but somewhat surprisingly, group projects still have a strong and significant effect.

**Table 1 around here **

With respect to internal political efficacy, we especially expected an open classroom climate to have positive effects (Hypothesis 2). The results in Table 2 show a strong effect of the control variables: Students in the French community feel significantly more politically efficacious, which is also the case for boys and students with a higher socioeconomic status. Contrary to Hypothesis 2, an open classroom climate and joint decision-making at school did not prove to be significantly related to political efficacy. Classroom instruction, on the other hand, did have a significant impact, suggesting that the feeling of political efficacy may have a cognitive foundation. 
These effects remained equally strong when the time-lagged test was performed and when students' internal efficacy in 2006 was controlled for (Table 2 - Model II). Moreover, internal efficacy is a political attitude that tends to remain stable, as the efficacy observed in 2006 is a strong predictor of students' efficacy levels in 2008. While Hypothesis 2 was not confirmed, classroom instruction was observed to have a strong effect on internal political efficacy.

\section{** Table 2 around here **}

The third political attitude to be investigated was political trust (Table 3). As was the case for students' interest in politics and political efficacy, higher socioeconomic status was found to have a positive effect on this attitude. There were no significant differences for gender or language group. For this attitude, Hypothesis 2 was confirmed, as political trust was found to be significantly related with the presence of an open classroom climate, an effect which remained significant even when the level of political trust in 2006 was controlled for (Model II).

Again, classroom instruction proved to have a significant effect. However, this effect was considerably weakened after controlling for 2006 levels and was only significant at the .10 level. Like the other attitudes investigated, political trust tends to remain stable over time: the level observed in 2006 is a strong predictor of 2008 level.

\footnotetext{
** Table 3 around here **
} 
As stated in Hypothesis 3, active learning strategies are expected to encourage pupils to become actively involved in politics. This hypothesis, however, was only partly confirmed: only school council membership was found to have a significant effect (Model I), but this was not the case for volunteering or visiting a public building. When the 2006 data for political participation were included, the effect of school council membership remained significant, while group projects and the presence of an open classroom climate lost their significance. Hypothesis 3 is thus only confirmed for school council membership, not for other active learning strategies. ${ }^{9}$

** Table 4 around here **

\section{Discussion}

Schools clearly have an effect on the politically relevant attitudes of adolescents in Belgium, even when individual background variables are controlled for. Most of these effects remained significant even when a time-lagged model was used, which enabled us to observe the development of each attitude between the two observations. Hypothesis 1 received unequivocal support, as classroom instruction in civic education was associated with the development of higher levels of political interest. Hypothesis 2 was only partially confirmed: the presence of an open classroom climate did have a significant effect on the development of political trust but was not significantly related to the development of a feeling of political efficacy. Formal instruction, however, proved significantly related to political efficacy, suggesting that this attitude is at least partly based on some form of cognitive insight into the structure of the political system. Active learning strategies, finally, were associated with 
higher levels of political participation but only for those students who were a member of the school council. This might suggest that only intensive forms of school engagement tend to have this effect. Overall, our hypotheses were largely confirmed: classroom instruction mainly had a cognitive effect, while an open classroom climate and membership of the school council had attitudinal and behavioral effects.

The results therefore suggest that there is no single optimal solution or best practice for civic education: various forms of civic education were found to have different outcomes. In recent years, there has been some discussion in the literature about the preferred methods of civic education. While more traditionally oriented authors have stressed the need for cognitive-based instruction, others have emphasized that schools should reflect a democratic society. Proponents of service learning, finally, argue that activities should resemble real-life forms of engagement as closely as possible. The results of the present study do not allow us to settle this discussion: given the differential pattern of outcomes observed, the current analysis does not allow us to privilege a specific form of civic education. Rather, the results suggest that educators or youth workers should select a specific educational approach depending on the desired outcome. It has to be noted, however, that in contrast to some earlier studies, classroom instruction was shown to be quite effective, as it also had an effect on feelings of political efficacy among late adolescents. From a policy perspective, our findings suggest that various forms of civic education should be combined into an eclectic model and selected according to the kinds of outcomes (cognitive, attitudinal or behavioral) that one wants to achieve.. Whether it is possible for schools and education systems to simultaneously meet all these sometimes contradictory requirements and combine them into an eclectic civic education model, self-evidently remains a matter for further discussion. 


\section{References}

Beck, P. A., \& Jennings, M. K. (1982). Pathways to participation. American Political Science Review, 76(1), 94-108.

Campbell, D. E. (2006). Why we vote: How schools and communities shape our civic life. Princeton: Princeton University Press.

Campbell, D. E. (2008). Voice in the Classroom: How an Open Classroom Climate Fosters Political Engagement Among Adolescents. Political behavior, 30(4), 437-454.

Claes, E., Hooghe, M., \& Marien, S. (forthcoming). School Experiences, Classroom Climate and Political Trust. A Two-Year Panel Study among Belgian Late Adolescents on the Impact of School Environment Characteristics on Political Trust. International Journal of Public Opinion Research.

Conway, J. M., Amel, E., \& Gerwien, D. (2009). Teaching and learning in the Social Context: A Meta-Analysis of Service Learning's Effects on Academic, Personal, Social, and Citizenship Outcomes. Teaching of Psychology, 36(4), 233-245.

Dalton, R. J. (2007). The good citizen. How a Younger Generation is Reshaping American Politics. Washington, D.C: CQ Press.

Delli Carpini, M. X., \& Keeter, S. (1996). What Americans know about politics and why it matters. New Haven: Yale University Press.

Easton, D., \& Dennis, J. (1967). The Child's Acquisition of Regime Norms: Political Efficacy. American Political Science Review, 61(1), 25-38.

Flanagan, C. A., \& Stout, M. (2010). Developmental Patterns of Social Trust between Early and Late Adolescence. Age and School Climate Effects. Journal of Research on Adolescence, 20(3), 748-773.

Fridkin, K. L., Kenney, P. J., \& Crittenden, J. (2006). On the Margins of Democratic Life: The impact of Race and Ethnicity on the Political Engagement of Young People. American Politics Research, 34(5), 605-626.

Galston, W. (2004). Civic education and political participation. PS-Political Science \& Politics, 37(2), 263-266.

Glanville, J. L. (1999). Political socialization or selection? Adolescent Extracurricular Participation and Political Activity in Early Adulthood. Social Science Quarterly, 10(2), 279-290.

Griffith, J. (1999). The school leadership/school climate relation. Identification of school configurations associated with change in principals. Educational Administration Quarterly, 35(2), 267-291.

Groves, R. M., \& Peytcheva, E. (2008). The impact of nonresponse rates on nonresponse bias: a meta-analysis. Public Opinion Quarterly, 72(2), 167-189.

Hart, D., Donnelly, T. M., Youniss, J., \& Atkins, R. (2007). High school community service as a Predictor of Adult Voting and Volunteering. American Educational Research Journal, 44(1), 197-219.

Hess, R. D., \& Torney, J. V. (1967). The development of political attitudes in Children. Chicago: Aldine.

Hooghe, M., \& Claes, E. (2009). Civic Education in Europe: Perspectives from the Netherlands, Belgium, and France. In J. Youniss \& P. Levine (Eds.), Engaging young people in civic life. Nashville: Vanderbilt University Press.

Hooghe, M., Quintelier, E., Claes, E., \& Dejaeghere, Y. (2009). The Belgian Political Panel Survey 2006-2008. Technical report. Leuven: K.U.Leuven. 
Hooghe, M., \& Wilkenfeld, B. (2008). The Stability of Political Attitudes and behaviors across Adolescence and Early Adulthood. A Comparison of Survey Data on Adolescents and Young Adults in Eight Countries. Journal of Youth and Adolescence, 37(2), 155-167.

Hox, J. J. (2010). Multilevel Analysis. Techniques and Applications. New York: Routledge.

Jennings, M. K., Stoker, L., \& Bowers, J. (2009). Politics across Generations: Family Transmission Reexamined. Journal of Politics, 71(3), 782-799.

Kahne, J., \& Sporte, S. (2008). Developing citizens: The impact of civic learning opportunities on students' commitment to civic participation. American Educational Research Journal, 45(3), 738-766.

Kahne, J., \& Westheimer, J. (2006). The Limits of Political Efficacy: Educating Citizens for a Democratic Society. PS: Political Science \& Politics, 39(2), 289-296.

Lerner, J., Phelps, E., Forman, Y., \& Bowers, E. (2009). Positive Youth Development. In R. M. Lerner \& L. Steinberg (Eds.), Handbook of Adolescent Psychology. 3rd edition (pp. 524-558). Hoboken: Wiley.

Lynn, P. (2009). Methodology of longitudinal surveys. Chichester: Wiley.

Malin, H. (2011). American Identity Development and Citizenship Education: A Summary of Perspectives and Call for New Research CONCLUSION. Applied Developmental Science, 15(2), 111-116.

McFarland, D., \& Thomas, R. (2006). Bowling young: How youth voluntary associations influence adult political participation. American Sociological Review, 401-425.

Olson, K., \& Witt, L. (2011). Are we keeping the people who used to stay? Changes in correlates of panel survey attrition over time. Social Science Research, 40(4), 10371050 .

Pasek, J., Feldman, L., Romer, D., \& Jamieson, K. (2008). Schools as incubators of democratic participation: Building long-term political efficacy with civic education. Applied Developmental Science, 12(1), 26-37.

Quintelier, E. (2008). Who is Politically Active: The Athlete, the Scouts Member or the Environmental Activist? Young People, Voluntary Engagement and Political Participation. Acta Sociologica, 51(4), 355-370.

Quintelier, E. (2010). The effect of schools on political participation: a multilevel logistic analysis. Research Papers in Education, 25(2), 137-154.

Sapiro, V. (2004). Not your parents' political socialization: Introduction for a new generation. Annual Review of Political Science, 7(1), 1-23.

Schmid, C. (2003). Fördert der Schulunterricht an Gymnasien das politische Interesse von Jugendlichen? Zeitschrift für Soziologie der Erziehung und Sozialisation, 23(4), 371384.

Smith, E. (1999). The Effects of Investments in the Social Capital of Youth on Political and Civic Behavior in Young Adulthood. Political Psychology, 20(3), 553-580.

Snow, D., Tebes, J., \& Arthur, M. (1992). Panel attrition and external validity in adolescent substance use research. Journal of Consulting and Clinical Psychology, 60(5), 804807.

Torney-Purta, J. (2002). The School's Role in developing Civic Engagement: A Study of Adolescents in Twenty-Eight Countries. Applied Developmental Science, 6(4), 203212.

Torney-Purta, J., Lehmann, R., Oswald, H., \& Schul, W. (2001). Citizenship and education in twenty-eight countries: civic knowledge and engagement at age fourteen. Amsterdam: IEA. 
Torney-Purta, J., \& Vermeer, S. L. (2006). Developing Citizenship Competencies from Kintergarten through Grade 12: A Background Paper for Policymakers and Educators. Denver: Education Commissions of the States.

Verba, S., Schlozman, K. L., \& Brady, H. E. (1995). Voice and equality: civic voluntarism in American Politics. Cambridge: Harvard University Press.

Youniss, J. (2011). Civic Education: What Schools Can Do to Encourage Civic Identity and Action. Applied Developmental Science, 15(2), 98-103.

Youniss, J., McLellan, J. A., \& Yates, M. (1997). What we know About Engendering Civic Identity. American Behavioral Scientist, 40(5), 620-631.

Zukin, C., Keeter, S., Andolina, M., Jenkins, K., \& Delli Carpini, M. X. (2006). A New Engagement? Political Participation, Civic Life, and the Changing American Citizen. New York: Oxford University Press. 
Appendix: Variables included in the analysis

\begin{tabular}{|c|c|c|c|c|}
\hline & Mean & $\begin{array}{l}\text { Standard } \\
\text { deviation }\end{array}$ & Frequencies & $\begin{array}{c}\text { Cronbach's } \\
\alpha \text { (if item } \\
\text { deleted) }\end{array}$ \\
\hline \multicolumn{5}{|c|}{ Dependent Variables } \\
\hline $\begin{array}{l}\text { Political trust } 2008(0=\text { no trust to } 10=\text { very } \\
\text { high trust })\end{array}$ & & & & \\
\hline 1. Federal parliament & 4.88 & 2.27 & & .88 \\
\hline 2. Regional parliament & 5.14 & 2.24 & & .86 \\
\hline 3. European parliament & 5.81 & 2.32 & & .91 \\
\hline 4. Government & 4.57 & 2.39 & & .90 \\
\hline 5. Political parties & 4.19 & 2.21 & & .92 \\
\hline Sum scale (0 to 10$)$ & 4.92 & 1.98 & & .92 \\
\hline $\begin{array}{l}\text { Political interest } 2008(1=\text { not interested to } 4 \\
=\text { very interested })\end{array}$ & 2.20 & 0.82 & & \\
\hline \multicolumn{5}{|l|}{$\begin{array}{l}\text { Political participation } 2008 \text { (In the past year, } \\
\text { did you } \ldots)(0=\text { no; } 1=\text { yes })\end{array}$} \\
\hline $\begin{array}{l}\text { 1. wear a badge, } \mathrm{t} \text {-shirt,... with a } \\
\text { political or social message }\end{array}$ & 0.18 & 0.39 & $18.3 \%(767)$ & .61 \\
\hline 2. Sign a petition & 0.45 & 0.50 & $45.0 \%(1894)$ & .63 \\
\hline 3. Participate in a legal manifestation & 0.09 & 0.29 & $9.3 \%(390)$ & .64 \\
\hline $\begin{array}{l}\text { 4. Collect or donate money to a worthy } \\
\text { cause }\end{array}$ & 0.45 & 0.50 & $44.2 \%(1857)$ & .65 \\
\hline 5. Boycott products & 0.23 & 0.42 & $23.0 \%(967)$ & .61 \\
\hline 6. Buycott products & 0.26 & 0.44 & $26.0 \%(1094)$ & .60 \\
\hline $\begin{array}{l}\text { 7. Forward an e-mail with a political } \\
\text { message }\end{array}$ & 0.16 & 0.37 & $16.4 \%(688)$ & .63 \\
\hline 8. Write or publish a political message & 0.05 & 0.23 & $5.4 \%(225)$ & .64 \\
\hline $\begin{array}{l}\text { 9. Attend a cultural show with political } \\
\text { content }\end{array}$ & 0.16 & 0.36 & $15.5 \%(653)$ & .63 \\
\hline $\begin{array}{l}\text { 10. Contact a politician to voice concern } \\
\text { about a certain situation }\end{array}$ & 0.06 & 0.23 & $5.6 \%(236)$ & .65 \\
\hline Sum-scale $(0$ to 10$)$ & 2.07 & 1.88 & & .65 \\
\hline \multicolumn{5}{|l|}{$\begin{array}{l}\text { Internal political efficacy } 2008(1=\text { do not } \\
\text { agree at all to } 5=\text { completely agree })\end{array}$} \\
\hline $\begin{array}{l}\text { 1. Sometimes politics is so complicated } \\
\text { that someone like me cannot } \\
\text { understand what is going on } \\
\text { (reversed) }\end{array}$ & 2.55 & 1.03 & & .68 \\
\hline $\begin{array}{l}\text { 2. I consider myself capable of } \\
\text { participating in politics }\end{array}$ & 2.56 & 1.05 & & .55 \\
\hline $\begin{array}{l}\text { 3. I think I have a pretty good } \\
\text { understanding of important issues } \\
\text { facing society }\end{array}$ & 3.08 & 0.93 & & .59 \\
\hline $\begin{array}{l}\text { 4. I think I would do as good a job as } \\
\text { most of the politicians elected }\end{array}$ & 2.62 & 1.02 & & .69 \\
\hline Sum-scale (1 to 5$)$ & 2.70 & 10.73 & & .69 \\
\hline
\end{tabular}




\begin{tabular}{|c|c|c|c|c|}
\hline \multicolumn{5}{|c|}{ Independent variables } \\
\hline Language $(0=$ Dutch, $1=$ French $)$ & 0.38 & 0.48 & & \\
\hline Gender $(0=$ girl, $1=$ boy $)$ & 0.49 & 0.50 & & \\
\hline SES 2006 (from -2.23 to 1.24 ) & 0.09 & 0.83 & & \\
\hline $\begin{array}{l}\text { Political trust } 2006(0=\text { no trust to } 10=\text { high } \\
\text { level of trust })\end{array}$ & & & & \\
\hline 1. Trust in federal parliament & 4.90 & 2.32 & & .90 \\
\hline 2. Trust in regional parliament & 4.98 & 2.29 & & .90 \\
\hline 3. Trust in European parliament & 5.55 & 2.44 & & .92 \\
\hline 4. Trust in federal government & 5.16 & 2.41 & & .91 \\
\hline 5. Trust in political parties & 4.22 & 2.36 & & .94 \\
\hline Sum-scale $(0-10)$ & 4.96 & 2.09 & & .93 \\
\hline $\begin{array}{l}\text { Political interest } 2006(1=\text { not interested to } 4 \\
=\text { very interested })\end{array}$ & 2.01 & 0.78 & & \\
\hline $\begin{array}{l}\text { Political participation } 2006 \text { (In the past year, } \\
\text { did you...) }(0=\text { no; } 1=\text { yes })\end{array}$ & & & & \\
\hline $\begin{array}{l}\text { 1. wear a badge, } t \text {-shirt,... with a } \\
\text { political or social message }\end{array}$ & 0.16 & 0.36 & $15.6 \%(556)$ & .56 \\
\hline 2. sign a petition & 0.41 & 0.49 & $41 \%(1726)$ & .57 \\
\hline 3. participate in a legal manifestation & 0.10 & 0.30 & $10.4 \%(435)$ & .58 \\
\hline $\begin{array}{l}\text { 4. collect or donate money to a worthy } \\
\text { cause }\end{array}$ & 0.45 & 0.50 & $45.2 \%(1897)$ & .59 \\
\hline 5. boycott products & 0.20 & 0.40 & $19.7 \%(828)$ & .56 \\
\hline 6. buycott products & 0.20 & 0.40 & $20.1 \%(842)$ & .54 \\
\hline $\begin{array}{l}\text { 7. forward an e-mail with a political } \\
\text { message }\end{array}$ & 0.12 & 0.33 & $12.0 \%(504)$ & .58 \\
\hline 8. write or publish a political message & 0.04 & 0.21 & $4.4 \%(185)$ & .59 \\
\hline $\begin{array}{l}\text { 9. attend a cultural show with political } \\
\text { content }\end{array}$ & 0.13 & 0.34 & $13.5 \%(566)$ & .58 \\
\hline $\begin{array}{l}\text { 10. contact a politician to voice concern } \\
\text { about a certain situation }\end{array}$ & 0.04 & 0.18 & $3.5 \%(147)$ & .60 \\
\hline Sum-scale (0 to 10$)$ & 1.83 & 1.70 & & .60 \\
\hline $\begin{array}{l}\text { Internal political efficacy } 2006 \quad(1=\text { most of } \\
\text { the time to } 5=\text { never think politics is so } \\
\text { complicated that I cannot understand what is } \\
\text { going on ) }\end{array}$ & 2.81 & 1.12 & & \\
\hline School council $(0=$ no member, $1=$ member $)$ & 0.06 & 0.24 & $6.2 \%(261)$ & \\
\hline Classroom instruction $(1=$ never to $4=$ often $)$ & & & & \\
\hline 1. The way parliament works & 1.53 & 0.69 & & .81 \\
\hline 2. The United Nations & 1.57 & 0.71 & & .81 \\
\hline 3. The European Union & 1.81 & 0.80 & & .81 \\
\hline 4. Federalism & 1.41 & 0.65 & & .81 \\
\hline 5. Elections & 1.73 & 0.74 & & .81 \\
\hline 6. Current political events & 2.11 & 0.87 & & .82 \\
\hline Sum-scale classes about politics (1 to 4 ) & 1.69 & 0.55 & & .84 \\
\hline Group projects $(1=$ never to $4=$ often $)$ & 2.30 & 0.80 & & \\
\hline $\begin{array}{l}\text { Volunteering }(0=\text { never to } 3=\text { more than } \\
\text { twenty hours })\end{array}$ & 0.18 & 0.47 & & \\
\hline & & & & \\
\hline
\end{tabular}




\begin{tabular}{|c|c|c|c|c|}
\hline \multicolumn{5}{|l|}{ Visits } \\
\hline $\begin{array}{l}\text { 1. Visited parliament or the town hall }(0 \\
=\text { no; } 1=\text { yes })\end{array}$ & 0.09 & 0.29 & $9.4 \%(392)$ & \\
\hline $\begin{array}{l}\text { 2. School visit by a politician or } \\
\text { important public figure }(0=\text { no; } 1= \\
\text { yes })\end{array}$ & 0.11 & 0.31 & $10.7 \%(445)$ & \\
\hline Sum-scale dummies (0 to 2 ) & 0.20 & 0.45 & & \\
\hline \multicolumn{5}{|l|}{$\begin{array}{l}\text { Joint decision making (A say in } \ldots 0=\text { no; } 1 \\
\text { = yes) }\end{array}$} \\
\hline 1. Problems at school & 0.41 & 0.49 & & .67 \\
\hline 2. Activities & 0.39 & 0.49 & & .66 \\
\hline 3. Scheduling of homework and exams & 0.27 & 0.45 & & .64 \\
\hline 4. Evaluating teachers & 0.25 & 0.43 & & .62 \\
\hline 5. Sanctions & 0.15 & 0.35 & & .63 \\
\hline 6. Rules & 0.23 & 0.42 & & .63 \\
\hline Sum-scale $(0$ to 6$)$ & 1.69 & 1.64 & & .68 \\
\hline \multicolumn{5}{|l|}{$\begin{array}{l}\text { Open classroom climate }(1=\text { totally disagree } \\
\text { to } 4=\text { totally agree })\end{array}$} \\
\hline $\begin{array}{l}\text { 1. Teachers present several sides of an } \\
\text { issue when explaining it in class }\end{array}$ & 2.71 & 0.76 & & .57 \\
\hline $\begin{array}{l}\text { 2. Students are encouraged to make up } \\
\text { their own minds about issues }\end{array}$ & 2.72 & 0.76 & & .46 \\
\hline $\begin{array}{l}\text { 3. Students feel free to express opinions } \\
\text { in class even when their opinions are } \\
\text { different from most of the other } \\
\text { students. }\end{array}$ & 2.71 & 0.64 & & .47 \\
\hline Sum-scale (1 to 4$)$ & 2.71 & 0.54 & & .60 \\
\hline
\end{tabular}


Table 1.

The effect of civic education on political interest

\begin{tabular}{|c|c|c|}
\hline & Model I & Model II \\
\hline Intercept & $0.705(0.293) *$ & $0.535(0.254) *$ \\
\hline Language $(1=$ French $)$ & $0.073(0.051) \mathrm{ns}$ & $0.041(0.045) \mathrm{ns}$ \\
\hline Gender $(1=$ male $)$ & $0.206(0.026) * * *$ & $0.144(0.024) * * *$ \\
\hline SES 2006 & $0.271(0.019) * * *$ & $0.177(0.017) * * *$ \\
\hline School council membership & $0.243(0.051) * * *$ & $0.134(0.047) * *$ \\
\hline Political interest 2006 & - & $0.409(0.015) * * *$ \\
\hline \multicolumn{3}{|l|}{ Class level variables } \\
\hline Classroom instruction & $0.231(0.057) * * *$ & $0.117(0.050) *$ \\
\hline Group projects & $0.166(0.042) * * *$ & $0.152(0.036) * * *$ \\
\hline Volunteering & $-0.022(0.074) \mathrm{ns}$ & $-0.014(0.063) \mathrm{ns}$ \\
\hline Visits & $-0.004(0.087) \mathrm{ns}$ & $-0.006(0.076) \mathrm{ns}$ \\
\hline \multicolumn{3}{|l|}{ School level variables } \\
\hline Joint decision making & $0.000(0.038) \mathrm{ns}$ & $0.011(0.033) \mathrm{ns}$ \\
\hline Open classroom climate & $0.198(0.105)^{\circ}$ & $0.055(0.091) \mathrm{ns}$ \\
\hline ICC class group & 0.078 & 0.066 \\
\hline ICC school & 0.054 & 0.055 \\
\hline $\mathrm{N}$ & 4,085 & 4,061 \\
\hline
\end{tabular}

Source: BPPS 2006-2008. Multilevel analysis. Standard errors are in parentheses. Dependent variable is 'political interest in $2008^{\prime}$ (from 1 to 4). Significance: ${ }^{\circ}: \leq 0.1 ; * \leq 0.05 ; * * \leq 0.01 ; * * * 0.001$. Initial ICC (intercept-only-model): class 0.110 - school: 0.065 . 
Table 2.

The effect of civic education on (internal) political efficacy

\begin{tabular}{lll}
\hline & \multicolumn{1}{c}{ Model I } & Model II \\
\hline Intercept & $2.029(0.241) * * *$ & $1.835(0.232) * * *$ \\
Language (1= French) & $0.135(0.042) * *$ & $0.089(0.041) *$ \\
Gender (1= male) & $0.417(0.023) * * *$ & $0.335(0.023) * * *$ \\
SES 2006 & $0.197(0.016) * * *$ & $0.190(0.016) * * *$ \\
Member of school council & $0.184(0.045) * * *$ & $0.152(0.045) * * *$ \\
Political efficacy 2006 & - & $0.153(0.010) * * *$ \\
Class level variables & & \\
Classroom instruction & $0.203(0.047) * * *$ & $0.205(0.045) * * *$ \\
Group projects & $0.039(0.035) \mathrm{ns}$ & $0.031(0.034) \mathrm{ns}$ \\
Volunteering & $-0.077(0.059) \mathrm{ns}$ & $-0.064(0.057) \mathrm{ns}$ \\
Visits & $-0.084(0.072) \mathrm{ns}$ & $-0.089(0.070) \mathrm{ns}$ \\
School level variables & & \\
Joint decision making & $0.007(0.086) \mathrm{ns}$ & $-0.068(0.083) \mathrm{ns}$ \\
Open classroom climate & & 0.002 \\
\hline ICC class group & & 0.000 \\
\hline
\end{tabular}

Source: BPPS 2006-2008. Multilevel analysis. Standard errors are in parentheses. Dependent variable is 'internal political efficacy in 2008' (from 1 to 5 ). Significance: ${ }^{\circ} \leq 0.1 ; * \leq 0.05 ; * * \leq 0.01 ; * * * \leq 0.001$. Initial ICC (intercept-only-model): class 0.035 - school: 0.018 . 
Table 3.

The effect of civic education on political trust

\begin{tabular}{|c|c|c|}
\hline & Model I & Model II \\
\hline Intercept & $1.547(0.861)^{\circ}$ & $1.118(0.732) \mathrm{ns}$ \\
\hline Language $(1=$ French $)$ & $-0.009(0.148) \mathrm{ns}$ & $-0.118(0.127) \mathrm{ns}$ \\
\hline Gender $(1=$ male $)$ & $-0.068(0.065) \mathrm{ns}$ & $-0.104(0.060)^{\circ}$ \\
\hline SES 2006 & $0.433(0.049) * * *$ & $0.313(0.044) * * *$ \\
\hline Member of school council & $0.039(0.125) \mathrm{ns}$ & $-0.041(0.115) \mathrm{ns}$ \\
\hline Political trust 2006 & - & $0.392(0.014) * * *$ \\
\hline \multicolumn{3}{|l|}{ Class level variables } \\
\hline Classroom instruction & $0.473(0.144) * * *$ & $0.215(0.124)^{\circ}$ \\
\hline Group projects & $0.155(0.111) \mathrm{ns}$ & $0.054(0.095) \mathrm{ns}$ \\
\hline Volunteering & $0.256(0.195) \mathrm{ns}$ & $0.182(0.166) \mathrm{ns}$ \\
\hline Visits & $-0.184(0.229) \mathrm{ns}$ & $-0.199(0.197) \mathrm{ns}$ \\
\hline \multicolumn{3}{|l|}{ School level variables } \\
\hline Joint decision making & $-0.231(0.112) *$ & $-0.155(0.096) \mathrm{ns}$ \\
\hline Open classroom climate & $0.938(0.314) * *$ & $0.618(0.268) *$ \\
\hline ICC class group & 0.039 & 0.019 \\
\hline ICC school & 0.024 & 0.019 \\
\hline $\mathrm{N}$ & 4037 & 3863 \\
\hline
\end{tabular}

Source: BPPS 2006-2008. Multilevel analysis. Standard errors are in parentheses. Dependent variable is 'political trust in 2008' (from 0 to 10 ). Significance: ${ }^{\circ} \leq 0.1 ; * \leq 0.05 ; * * \leq 0.01 ; * * \leq 0.001$. Initial ICC (intercept-only-model): class 0.106 - school: 0.081 . 
Table 4.

The effect of civic education on political participation

\begin{tabular}{|c|c|c|}
\hline & Model I & Model II \\
\hline Intercept & $-0.435(0.691) \mathrm{ns}$ & $-0.392(0.599) \mathrm{ns}$ \\
\hline Language $(1=$ French $)$ & $0.656(0.121) * * *$ & $0.429(0.105) * * *$ \\
\hline Gender $(1=$ male $)$ & $-0.110(0.060)^{\circ}$ & $-0.016(0.053) \mathrm{ns}$ \\
\hline SES 2006 & $0.513(0.044) * * *$ & $0.283(0.039) * * *$ \\
\hline Member of school council & $0.726(0.118) * * *$ & $0.280(0.106) * *$ \\
\hline Political participation 2006 & - & $0.534(0.016) * * *$ \\
\hline \multicolumn{3}{|l|}{ Class level variables } \\
\hline Classroom instruction & $0.339(0.131) *$ & $0.202(0.113)^{\circ}$ \\
\hline Group projects & $0.234(0.097) *$ & $0.100(0.084) \mathrm{ns}$ \\
\hline Volunteering & $0.127(0.170) \mathrm{ns}$ & $-0.011(0.145) \mathrm{ns}$ \\
\hline Visits & $0.035(0.203) \mathrm{ns}$ & $-0.150(0.174) \mathrm{ns}$ \\
\hline \multicolumn{3}{|l|}{ School le vel variables } \\
\hline Joint decision making & $-0.129(0.090) \mathrm{ns}$ & $-0.064(0.078) \mathrm{ns}$ \\
\hline Open classroom climate & $0.483(0.249)^{\circ}$ & $0.318(0.216) \mathrm{ns}$ \\
\hline ICC class group & 0.024 & 0.016 \\
\hline ICC school & 0.005 & 0.007 \\
\hline $\mathrm{N}$ & 4013 & 3880 \\
\hline
\end{tabular}

Source: BPPS 2006-2008. Multilevel analysis. Standard errors are in parentheses. Dependent variable is 'political participation in 2008' (from 0 to 10 ). Significance: ${ }^{\circ} \leq 0.1 ; * \leq 0.05 ; * * 0.01 ; * * * \leq 0.001$. Initial ICC (intercept-only-model): class 0.109 - school: 0.082 . 


\section{Endnotes}

${ }^{1}$. In the literature, it is customary to distinguish between internal political efficacy (where responsibility is attributed to the individual) and external political efficacy (where responsibility is attributed to the political system). Given our current focus on individual level outcomes, we will limit ourselves to internal political efficacy.

${ }^{2}$. The analysis shows that attrition was higher among French-speaking boys than among other groups. The weighing coefficient introduced for this selective attrition rate, however, remained limited to 1.18 (Hooghe et al., 2009).

3 . Department for Educational Development (DED). (2001). Aims and goals, from http://www.ond.vlaanderen.be/dvo/english/index.htm

4. Note that the Cronbach's alpha of some scales remains at the .60 level, which implies that these results should be interpreted with some caution.

5 . Correlation analysis shows that the correlation between the occurrences of these forms remains limited and usually does not exceed the .2 level, thus confirming that these are indeed distinct educational practices.

${ }^{6}$. For the sake of accuracy, we also conducted the analysis with the single item in both waves, which did not lead to different results.

7. In a separate analysis, we also included these variables at the individual level (results available from the authors). While this generally led to somewhat weaker effects, it did not lead to substantively different conclusions.

8. In an alternative operationalization, the variables 'joint decision making' and 'open classroom climate' were also aggregated to the class level and not to the school level. The results of these analyses, however, were identical to those from the main analysis (results available upon request). It has to be noted that the measure for an open classroom climate averaged by classes correlated 0.551 with the measure averaged by schools. For joint decision making, the correlation between both levels of aggregation was even 0.674.

${ }^{9}$. We also controlled for all possible interaction effects, but none of these led to significant or meaningful results. 